\title{
UPAYA PELESTARIAN PENCAK SILAT DAN WISATA BANTEN LAMA BERBASIS DIGITAL MARKETING GUNA MELESTARIKAN WARISAN BUDAYA BANTEN
}

\author{
Ranthy Pancasasti ${ }^{1}$, Pranajaya Kusuma ${ }^{2}$, Sri Ndaru Arthawati ${ }^{3}$, Tris Sudarto ${ }^{4}$ \\ ${ }^{1,2,3}$ Universitas Sultan Ageng Tirtayasa, Jl Kampus Terpadu Sindang Sari, Pabuaran, Serang, Banten, Indonesia \\ Email: ranthyipb@gmail.com
}

\begin{abstract}
This community service activity (PPM) was carried out in Serang City in partnership with the Assyfa Pencak Silat Padepokan and the Manager of Old Banten Tourism Places, namely Explore Banten Travel. Serang City as the capital of Banten Province holds various artistic, cultural and tourist potentials, which if managed properly, can generate large income for the community and the government of Serang City. For example, Pencak Silat and Banten Lama tourism which is one of the historical heritage of the people of Banten. On the other hand, there are still many people and tourists (local and foreign) who do not know about Pencak Silat and Banten Lama tourism. So it is deemed necessary to hold a community service program (PPM) in the form of socialization and education about Pencak Silat and Old Banten tourism so that it remains sustainable and known to foreign countries. The method used in this PPM is in the form of socialization and education based on digital marketing through social media. The results of this PPM are in the form of documentary films on the YouTube Channel and content on social media about Pencak Silat and Banten Lama tourism, in order to participate in helping government programs, promoting Pencak Silat and Banten Lama tourism so that they remain sustainable and are known to foreign countries.
\end{abstract}

Keywords: Pencak Silat; Banten Lama; Socialization and Education; Digital Marketing; Social Media.

\begin{abstract}
ABSTRAK
Kegiatan pengabdian pada masyarakat (PPM) ini dilakukan di Kota Serang bermitra dengan Padepokan Pencak Silat Assyfa dan Pengelola Tempat Wisata Banten Lama, yaitu Explore Banten Travel. Kota Serang sebagai ibukota Provinsi Banten menyimpan berbagai potensi seni, budaya dan tempat wisata, dimana jika dikelola dengan baik, maka dapat menghasilkan pendapatan yang besar bagi masyarakat dan pemerintah Kota Serang. Contohnya, Pencak Silat dan wisata Banten Lama yang merupakan salah satu peninggalan sejarah masyarakat Banten. Di sisi lain, masih banyak masyarakat dan turis (lokal dan mancanegara) yang belum mengetahui tentang Pencak Silat dan wisata Banten Lama. Sehingga dipandang perlu untuk diadakannya program pengabdian pada masyarakat (PPM) dalam bentuk sosilisasi dan edukasi tentang Pencak Silat dan wisata Banten Lama agar tetap lestari dan dikenal sampai ke manca negara. Metode yang digunakan dalam PPM ini berupa sosilisasi dan edukasi berbasis digital marketing melalui social media. Hasil PPM ini berupa film dokumenter di YouTube Channel dan konten di social media tentang Pencak Silat dan wisata Banten Lama, dalam rangka ikut serta membantu program pemerintah, mempromosikan Pencak Silat dan wisata Banten Lama agar tetap lestari dan dikenal sampai ke manca negara.
\end{abstract}

Kata kunci: Pencak Silat, Banten Lama, Sosialisasi Dan Edukasi, Digital Marketing, Social Media

\section{PENDAHULUAN}

Banten pada masa lalu merupakan sebuah daerah dengan kota pelabuhan yang sangat ramai , serta dengan masyarakat yang terbuka dan makmur. Banten pada abad ke 5 merupakan 
bagian dari Kerajaan Tarumanagara. Salah satu prasasti peninggalan Kerajaan Tarumanagara adalah Prasasti Cidanghiyang atau prasasti Lebak, yang ditemukan di kampong lebak di tepi CiDanghiyang, Diawali dengan penguasaan Kota Pelabuhan Banten, yang dilanjutkan dengan merebut Banten Girang dari Pucuk Umun pada tahun 1527, Maulana Hasanuddin, mendirikan Kesultanan Banten di wilayah bekas Banten Girang. Dengan demikian pemerintahan di Jawa Barat dilanjutkan oleh Kesultanan Banten. Banten dalam memerangi kolonialisme para penjajah. Pada saat ini pun Banten masih dikenal dan diakui secara luas dengan pendekar dan jawaranya, sebutan untuk orang-orang yang mahir dalam ilmu silat.

Perkembangan dan penyebaran silat secara historis di Nusantara mulai tercatat ketika penyebaran dan pengajarannya banyak dipengaruhi oleh kaum ulama. Pencak silat merupakan seni bela diri yang berakar dari budaya asli bangsa Indonesia disinyalir dari abad ke-VII masehi silat sudah menyebar ke ploksok nusantara. Seiring dengan penyebaran agama Islam pada abad ke-XV di Nusantara. Namun kemajuan jaman, modernisasi dan globalisasi telah menggeser kebudayaan local pribumi yang dipinggirkan, diasingkan serta disingkirkan dari kehidupan masyarakat dari tempat dimana kebudayaan itu lahir. Karya- karya seni tersebut merupakan aset budaya yang harus dijaga dan dilestarikan keadaannya. Menjaga dari tergerusnya oleh arus budaya luar atau globalisasi yang mengarahkan bangsa pada identitas budaya yang tidak jelas. Kehilangan akar budaya sudah pasti akan terjadi pemutusan generasi. Diganti oleh generasi hedonis: glamor sekuler, kebarat-baratan, gengsi, sok-pamer, dan kehilangan religiusitas. Selain itu, pariwisata juga mempunyai pengaruh terhadap Pendapatan Asli Daerah (PAD) bagi Pemerintah Daerah.

Kota Serang merupakan salah satu daerah di Banten yang memiliki aneka ragam tempat wisata. Salah satu objek wisata yang diunggulkan adalah Kota Kuno Banten atau Banten Lama. Kota Kuno Banten atau Banten Lama adalah situs yang merupakan sisa kejayaan Kerajaan Banten. Banten Lama banyakmenyimpan tentang perkembangan sejarah Kesultanan Islam di Banten, untuk itu setiap tahunnya selalu ada Penziarah dan Wisatawan dating untuk menikmati keindahan peninggalan Kesultanan Banten, namun sayang banyak bangunannya yang tidak terurus, karena banyaknya Pemukiman dan kadang tempat- tempat tersebut dijadikan tempat berjualan bagi penduduk sekitar, dijadikan lapangan bola, dan sebagainya. Tetapi masyarakat lebih banyak tertarik berwisata ke Kawasan Pantai yang ada di Banten dibandingkan berwisata ke Banten Lama, dikarenaka masih belum terawatnya situs-situs peninggalan sejarah yang mengakibatkan kurang nya daya tarik wisatawan. Berdasarkan pemaparan tersebut, maka dipandang perlu adanya analisis faktor- faktor daya tarik berwisata di Banten lama sebagai salah satu referensi tempat wisata di Kota Serang Provinsi, yang bertujuan untuk menarik wisatawan lokal maupun mancanegara yang nantinya akan menghidupkan perekonomian masyarakat 
setempat, melestarikan nilai kearifan lokal sejarah perjuangan rakyat Banten, serta dapat mengenalkan situs-situs peninggalan sejarah dan juga dapat meningkatkan wisatarohani kepada masyarakat luar. Salah satu konsepnya, yaitu dengan cara mengajak kerja sama agen Travel Dan Content Creator agar Banten Lama dapat dipromosikan lewat media sosial dan menjadi salah satu referensi wisata, sehingga masyarakat luar pun bisa dengan mudah datang ke Banten Lama dengan menggunakan travel. Maksud dari adanya kerja sama dengan Agen Travel Dan Content Creator yang ada di Daerah Banten. Sejarah garis besar, maksud dari Mengajak Kerja Sama Agen Travel Dan Content Creator ini untuk mendorong masyarakat agar berwisata ke Banten Lama dan menjadikan Banten Lama sebagai salah satu referensi objek wisata yang kaya akan nilai budaya, sejarah dan rohani.

Masyarakat serta Pemerintah Kota Serang dalam rangka menciptakan pembangunan pariwisata berkelanjutan secara sistematis dan bertahap dengan perspektif jangka panjang guna meningkatkan taraf hidup dan ekonomi masyarakat, khususnya masyarakat yang tinggal di sekitar Banten Lama.Mitra dalam kegiatan ini adalah padepokan assyifa dan Explore BantenTravel Tugas umum dari Padepokan Assyifa dan Explore Banten Travel bersama tim Penelitian adalah merumuskan strategi Upaya Pelestarian Pencak Silat Dan Wisata Banten Lama Berbasis Digital Marketing Guna Melestarikan Warisan Budaya Di Kota Serang Provinsi Banten, sehingga dapat meningkatkan daya tarik pengunjung untuk berwisata di Banten Lama yang kental akan peninggalan sejarah. Metode/pendekatan yang digunakan untuk meningkatkan daya tarik wisata Banten Lama adalah deskriptif, dengan alat analisis SWOT Analysis, dimulai dari perencanaan pelaksanaan sampai dengan evaluasi, yang dilakukan secara langsung maupun tidak langsung, misalnya dengan bekerjasama dengan agen travel dancontent creator, sosialisasi ke sekolah, pameran wisata, revitalisasi tempat wisata, membuat film documenter serta melakukan promosi melalui media sosial.

\section{METODE}

Untuk mendukung realisasi pembinaan Upaya Pelestarian Pencak Silat Dan Wisata Banten Lama Berbasis Digital Marketing Guna Melestarikan Warisan Budaya Di Kota Serang Provinsi Banten dengan keterampilan dan penggunaan media sosial kepada masyarakat, khususnya masyarakat wilayah Banten Lama, tim pengusul program melakukan serangkaian tahapan dalam melaksanakan solusi dari permasalahan mitra sebagai berikut:

1. Membangun mindset masyarakat bahwa wisata Banten Lama tidak hanya sebagai sarana hiburan semata sehingga kurang diminati oleh wisatawan dalam daerah maupun luar daerah.

2. Mewujudkan upaya melestarikan wisata Banten Lama yang memiliki nilai kearifan lokal sebagai keunggulan industri melalui metode digital marketing. 
3. Mewujudkan pengembangan ekonomi para pelaku penduduk wisata Banten Lama yang mandiri serta berdaya saing.

4. Adanya pembuatan film dokumenter dan pembuatan konten di social media untuk mempromosikan wisata Banten Lama serta mengikuti wisata di Banten Lama guna melestarikan warisan budaya.

5. Mengenalkan kepada masyarakat bahwa pecak silat bukan hanya merupakan ajang bela diri namun juga merupakan sebuah kesenian yang bisa dinikmati.

6. Menciptakan cara untuk menjadikan kesenian pencak silat dengan menumbuhkan nilai eksistensi kesenian Pencak Silat di kalangan masyarakat.

7. Mewujudkan upaya pelastarian kesenian pencak silat kepada masyarakat dengan strategi pemasaran dan promosi berbasis digital marketing pada kesenian pencak silat, seiring perkembangan zaman.

8. Mewujudkan pengembangan ekonomi pada pelaku kesenian pencak silat yang mandiri dan berdaya saing.

\section{Metode Pendekatan yang Ditawarkan Untuk Menyelesaikan persoalan mitra}

Pengabdian kepada masyarakat ini memiliki fokus memberikan keterampilan dan wawasan wirausaha kepada masyarakat Banten Lama dalam rangka meningkatkan pendapatan masyarakat dan secara tidak langsung meningkatkan kesejahteraan serta wisata Banten Lama dan pecak silat sebagai budaya dan kesenian di Kota Serang. Metode yang digunakan dalam kegiatan ini adalah:

1. Membangun mindset masyarakat bahwa wisata Banten Lama sangat dimintai oleh wisatawan luar daerah maupun manca negara. Metode/pendekatan yang digunakan Banten Lama tidak hanya sebagai sarana hiburan adalah partisipatif, mulai dari perencanaan, pelaksanaan, sampai semata sehingga kurang di minati oleh wisatawan dengan evaluasi yang dilakukan dalam Daerah maupun luar Daerah pelaksanaan, sampai dengan evaluasi yang dilakukan secara langsung dan tidak langsung yaitu melalui pertunjukan/ festival, temu aplikasi di sosmed dengan paket wisata, mengadakan edukasi/penyuluhan secara berkelanjutan kepada masya rakat dan wisatawan tentang latar belakang sejarah budaya Banten Lama sebagai: (a) warisan budaya, dan (b) terdapat nilai ekonomi di dalamnya.

2. Mewujudkan upaya melestarikan wisata Banten Lama yang memiliki nilai kearifan lokal. Metode/pendekatan yang digunakan adalah partisipatif, mulai dari perencanaan, pelaksanaan, sampai keunggulan industri dan digital marketing dengan evaluasi yang dilakukan pelaksanaan, sampai dengan evaluasi yang dilakukan secara langsung dan tidak langsung 
yaitu melalui: (a) mengajak content creator untuk melakukan video perjalanan dengan mengenalkan wisata Banten Lama, dan (b) mengiklankan tur wisata Banten Lama.

3. Mewujudkan pengembangan ekonomi pada pelaku penduduk wisata banten lama yang mandiri serta berdaya saing. Metode/pendekatan yang digunakan adalah partisipatif, mulai dari penduduk wisata banten lama yang mandiri serta perencanaan, pelaksanaan, sampai berdaya saing dengan evaluasi, yang dilakukan secara langsung maupun tidak langsung, yaitu melalui: (a) membangun usaha kecil dan menengah (UKM), (b) membangun usaha kecil menengah (UKM) oleh-oleh/souvenir khas Banten, yang terletak di daerah kasemen Kota Serang.

4. Mewujudkan upaya pelastarian kesenian pencak silat kepada masyarakat dengan strategi pemasaran dan promosi berbasis digital marketing pada kesenian Pencak silat dengan mengikuti seiring perkembangan zaman. Metode/pendekatan yang digunakan kepada masyarakat dengan strategi pemasaran dan adalah partisipatif, mulai dari promosi berbasis digital marketing pada kesenian perencanaan, pelaksanaan, sampai Pencak silat dengan mengikuti seiring perkembangan dengan evaluasi, yang dilakukan secara zaman langsung maupun tidak langsung, yaitu melalui: (a) membuat video dokumenter dan konten dimedia sosial atau dengan melakukan pertunjukan secara live agar masyarat dapat mengakses dengan mudah yang bertujuan mengenalkan Pencak silat lebih jauh lagi, dan (b) mengikuti pameran kesenian, baik tingkat daerah maupun nasional mengenai kesenian Pencak silat.

5. Mewujudkan pengembangan ekonomi pada pelaku penduduk untuk kesenian pencak silat yang mandiri dan berdaya saing Metode/pendekatan yang digunakan penduduk untuk kesenian pencak silat yang mandiri adalah partisipatif, mulai dari dan berdaya saing perencanaan, pelaksanaan, sampai dengan evaluasi, yang dilakukan secara langsung maupun tidak langsung, yaitu melalui : (a) membangun usaha kecil menengah (UKM) Souvenir dengan khas kesenain Pencak Silat, (b) memberikan pelatihan dasar membangun usaha kecil dan menengah (UKM), dan (c) menciptakan sebuah strategi pemasaran guna mempromosikan kesenian Pencak Silat berbasis digital marketing, seperti: (1) membuat konten di media sosial, (2) mengajak kerja sama content creator untuk membuat sebuah video Marketing guna melihatkan kesenian Pencak Silat, dan (3) perluasan pemahaman mengenai Digital Marketing sebagai media untuk mempromosikan kesenian Pencak Silat. 


\section{HASIL DAN PEMBAHASAN}

\section{Banten Lama dan Pencak Silat}

\section{a. Banten Lama}

Pada Gambar 1. Kawasan Banten Lama di Kota Serang banyak meninggalkan bangunan yang memiliki nilai sejarah tinggi. Salah satu bangunan yang masih tersisa adalah Keraton Kaibon dan Keraton Surosowan. Keraton kaibon ini menjadi keraton kedua di Banten setelah Keraton Surosowan. Berbeda dengan Keraton Surosowan, sebagai pusat pemerintahan, Keraton Kaibon dibangunsebagai tempat tinggal Ratu Aisyah.

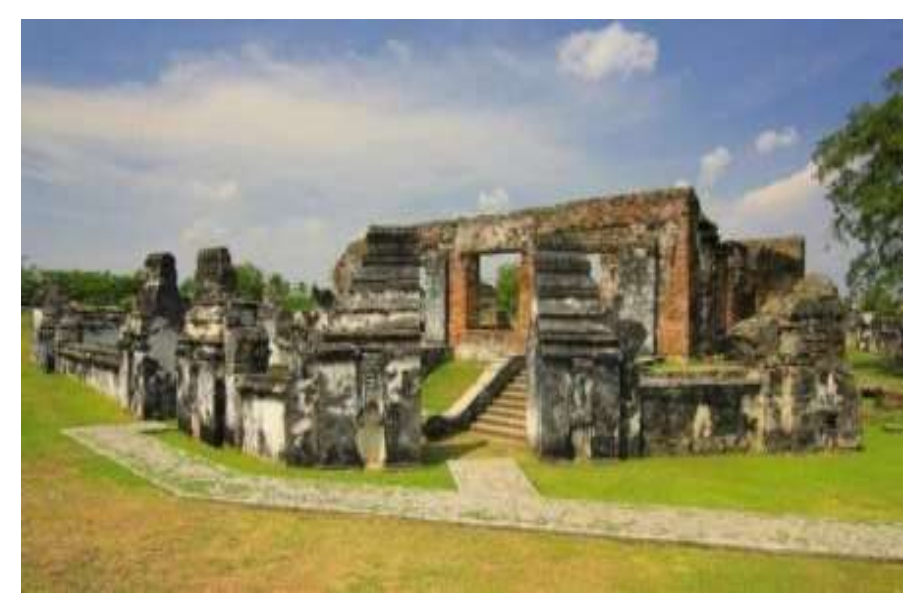

\section{Gambar 1. Banten Lama dengan bangunan Keraton Kaibon}

Pada Gambar 2, Banten Lama adalah situs yang merupakan sisa kejayaan Kerajaan Banten. Di tempat ini terdapat banyak situs peninggalan dari Kerajaan Banten salah satunya yaitu Masjid Agung Banten

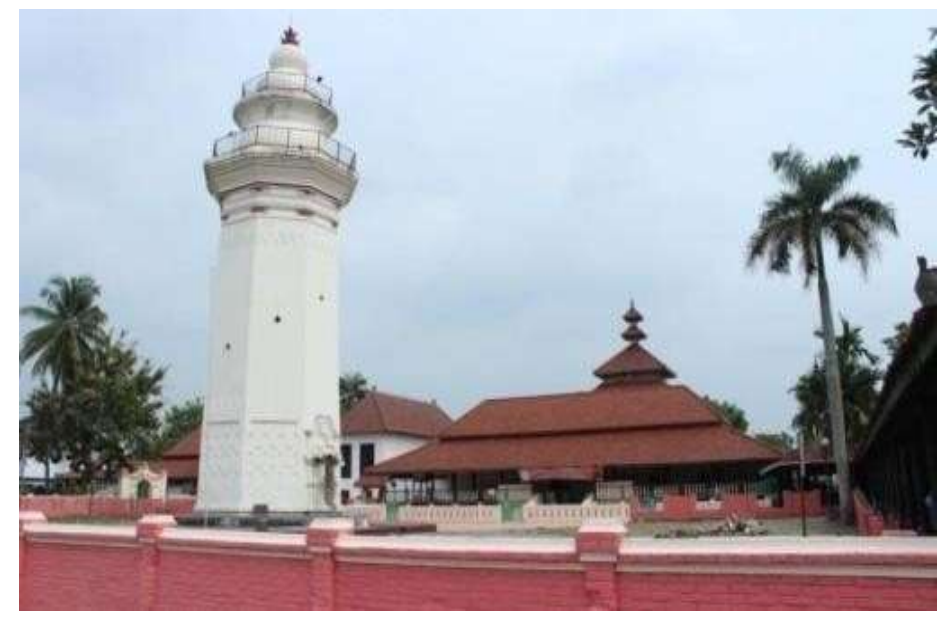

Gambar 2. Masjid Agung Banten Lama 


\section{b. Pencak Silat}

Pada Gambar 3 adalah gambaran mengenai unsur nilai seni pada pencak silat yang merupakan wujud budaya dalam kaidah gerak dan irama yang tunduk pada keseimbangan, keselarasan dan keserasian. Pencak silat memiliki gerakan-gerakan yang indah dan memiliki nilai estetika, yang memiliki nilai dan maknanya. Gerakan pada seni ini juga mengandung makna tentang kehidupan, bagaimana melindungi manusia yang lainnya dengan kemampuan pencak silat yang kita miliki, sehingga ada rasa aman dan kedamaian. Gerakannya terdiri dari tendangan, kuda-kuda, tangkisan dan jurus lainnya sehingga menciptakan perpaduan gerakan yang keren.

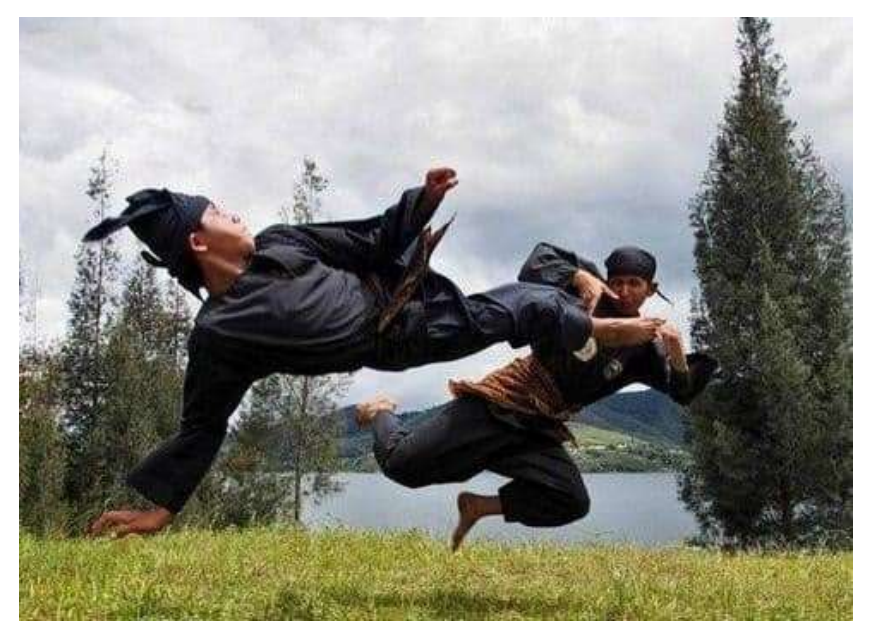

Gambar 3. Seni Bela Diri Pecak Silat

\section{Sejarah Banten Lama dan Pecak Silat}

\section{a. Sejarah Banten Lama}

Banten pada masalalu merupa kan sebuah daerah dengan kota pelabuhan yang sangat ramai, serta dengan masyarakat yang terbuka dan makmur. Banten pada abad ke 5 merupakan bagian dari Kerajaan Tarumanagara. Salah satu prasasti peninggalan Kerajaan Taruma nagara adalah Prasasti Cidanghiyang atau prasasti Lebak, yang ditemukan di kampong lebak di tepi Ci Danghiyang, Kecamatan Munjul, Pandeglang, Banten. Seperti dinyatakan oleh Tome Pires, penjelajah Portugis pada tahun 1513, Banten menjadi salah satu pelabuhan penting dari Kerajaan Sunda. Menurut sumber Portugis tersebut, Banten adalah salah satu pelabuhan kerajaan itu selain pelabuhan Pontang, Cigede, Tamgara, Kalapa, dan Cimanuk. Diawali dengan penguasaan Kota Pelabuhan Banten, yang dilanjutkan dengan merebut Banten Girang dari Pucuk Umun pada tahun 1527, Maulana Hasanuddin, mendirikan Kesultanan Banten di wilayah bekas Banten Girang. Dengan demikian pemerintahan di Jawa Barat dilanjutkan oleh Kesultanan Banten. Hal itu ditandai dengan di boyongnya Palangka Sriman Sriwacana, tempat duduk kala seorang raja dinobatkan, dari Pakuan Pajajaran ke Surasowan di Banten oleh 
pasukan Maulana Yusuf. Batu berukuran 200 x 160 x $20 \mathrm{~cm}$ itu terpaksa diboyong ke Banten karena tradisi politik waktu itu mengharuskan demikian. Ketika sudah menjadi pusat Kesultanan Banten, sebagaimana dilaporkan oleh J. de Barros, Banten merupakan pelabuhan besar di Asia Tenggara, sejajar dengan Malaka dan Makassar. Kota Banten terletak di pertengahan pesisir sebuah teluk, yang lebarnya sampai tiga mil. Pada awal abad ke-17 Masehi, Banten merupakan salah satu pusat perniagaan penting dalam jalur perniagaan internasional di Asia. Ketika orang Belanda tiba di Banten untuk pertama kalinya, orang Portugis telah lama masuk ke Banten. Kemudian orang Inggris mendirikan loji di Banten dan di susul oleh orang Belanda.

\section{Lokasi Wisata Banten Lama}

Wisata Banten Lama berada di Desa Banten Kecamatan Kasemen Kota Serang (42191). Kota Kuno Banten atau Banten Lama adalah situs yang merupakan sisa kejayaan Kerajaan Banten. Letaknya relatif tidak jauh dari kota Jakarta, dapat ditempuh sekitar 2 jam dari Jakarta. Di tempat ini terdapat banyak Situs peninggalan dari Kerajaan Banten, di antaranya, Istana Surosoan, Masjid Agung Banten, Situs Istana Kaibon, Benteng Speelwijk, Danau Tasikardi, Meriam Ki Amuk, Pelabuhan Karangantu, Vihara Avalokitesvara.

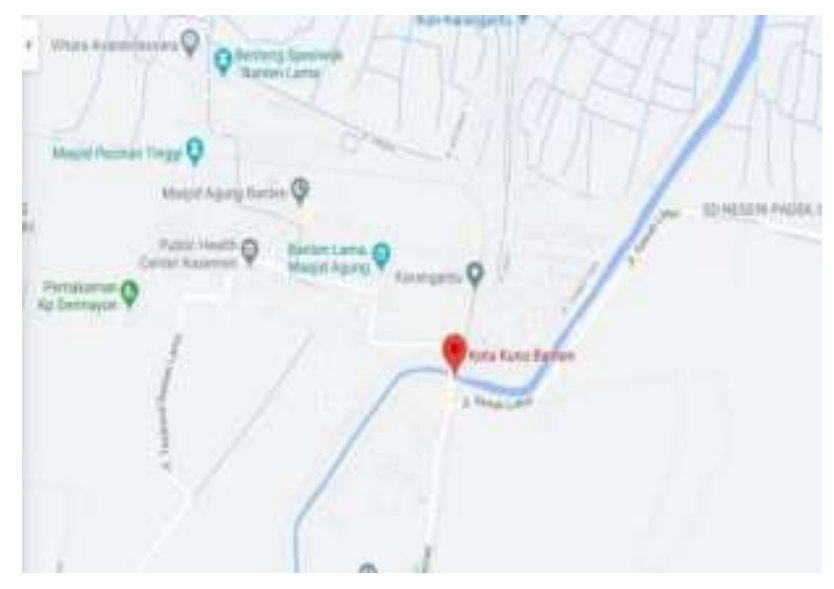

Gambar 4. Lokasi PPM Banten Lama

\section{Kerja Sama Travel Dan Content Creator}

Mengajak kerja sama agen Travel Dan Content Creator agar Banten Lama dapat dipromosikan lewat media sosial dan menjadi salah satu referensi wisata, sehingga masyarakat luar pun bisa dengan mudah datang ke Banten Lama dengan menggunakan travel. Maksud dari adanya kerja sama dengan Agen Travel Dan Content Creator yang ada di Daerah Banten. Yaitu : (1) Mengenalkan daya tarik Seni Budaya dan Wisata Banten Lama, (2) Mengenalkan Seni Budaya Pencak Silat dan Wisata Banten Lama kepada masyarakat luar, (3) Menjadikan 
Banten Lama sebagai salah satu referensi objek wisata, serta (4a) membuat video dokumenter dan konten dimedia sosial yang bertujuan mengenalkan Seni Budaya Pencak Silat dan Wista Banten Lama lebih jauh lagi (4b) mengikuti pameran wisata, baik tingkat daerah maupun nasional untuk mengenalkan Seni Budaya dan berbagai macam wisata yang ada di Banten Lama. Tujuan utama Mengajak Kerja Sama Agen Travel Dan Content Creator ini untuk mendorong masyarakat agar berwisata ke Banten Lama dan menjadikan Banten Lama sebagai salah satu referensi objek wisata yang kaya akan nilai budaya, sejarah dan rohani.

\section{Media Sosial Wisata Banten Lama}

Media sosial merupakan program usulan dari Tim PPM yang sudah terselenggarakan dengan menggunakan dua media sosial yang mayoritas masyarakat memiliki media sosial tersebut yaitu Facebook dan Instagram untuk Menciptakan strategi pemasaran berbasis digital matketing pada pariwisata sehingga masyarakat lebih mengenal wisata Banten Lama, seperti: membuat video dokumenter dan konten dimedia sosial yang bertujuan mengenalkan Banten Lama lebih jauh lagi.

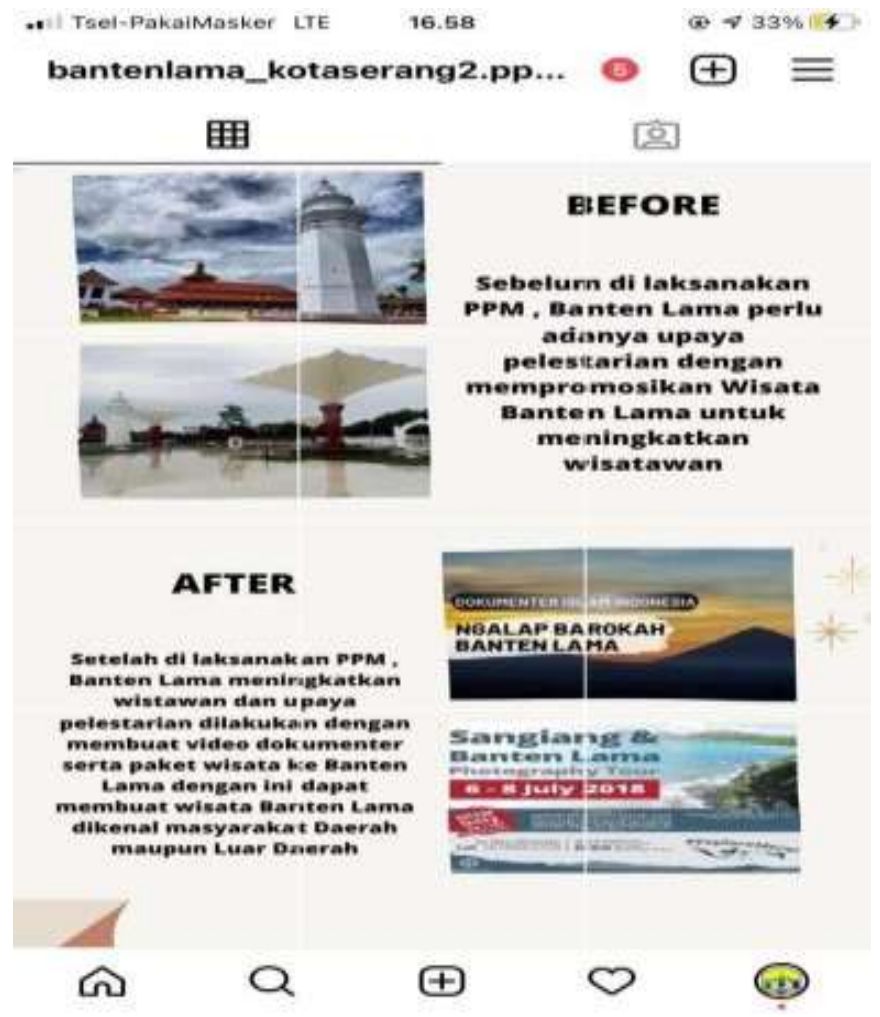

Gambar 5. Akun instagram banten lama

\section{b. Sejarah Pencak Silat}

Pencak silat merupakan seni bela diri yang berakar dari budaya asli bangsa Indonesia disinyalir dari abad ke-VII masehi silat sudah menyebar ke ploksok nusantara. Seiring 
dengan penyebaran agama Islam pada abad ke-XV di Nusantara. Pencak Silat Banten mulai dikenal seiring dengan berdirinya kerajaan Islam banten yang didirikan pada abad ke-XV masehi dengan raja pertamanya Sultan Hasanudin. Perkembangan pencak silat pada saat itu tidak terlepas dari dijadikanya silat sebagai alat untuk penggemblengan para prajurit kerajaan sebagai bekal ketangkasan bela Negara yang diajarkan oleh para guru silat yang menguasai berbagai aliran. Namun kemajuan jaman, modernisasi dan globalisasi telah menggeser kebudayaan lokal pribumi yang dipinggirkan, diasingkan serta disingkirkan dari kehidupan masyarakat dari tempat dimana kebudayaan itu lahir. Di satu sisi, rasionalisasi dan perkembangan iptek telah memodernisasikan kehidupan orang Sunda untuk mempermudah kehidupan mereka. Tetapi resiko dan konsekuensinya pun sangat besar yaitu hancurnya pranata pranata sosial, institusi sosial, institusi keagamaan dan memudarnya tradisionalisme kesundaan, salah satu contohnya adalah kesenian bela diri Pencak Silat, memang masih dapat kita temukan ditemukan dalam acara seremonial tertentu seperti kawinan, sunatan atau hiburan- hiburan yang lainnya. Tapi tanpaknya tak sulit untuk terima bahwasannya memang intensitas hadirnya kesenian-kesenian itu semakin jarang dan terus semakin berkurang. Karya-karya seni tersebut merupakan aset budaya yang harus dijaga dan dilestarikan keadaannya.

\section{Lokasi Pencak silat}

JL.KH Fatah Hasan No.1 Cijawa Masjid, Rt.003/Rw.001 Kel.Cipare Kecamatan Serang.

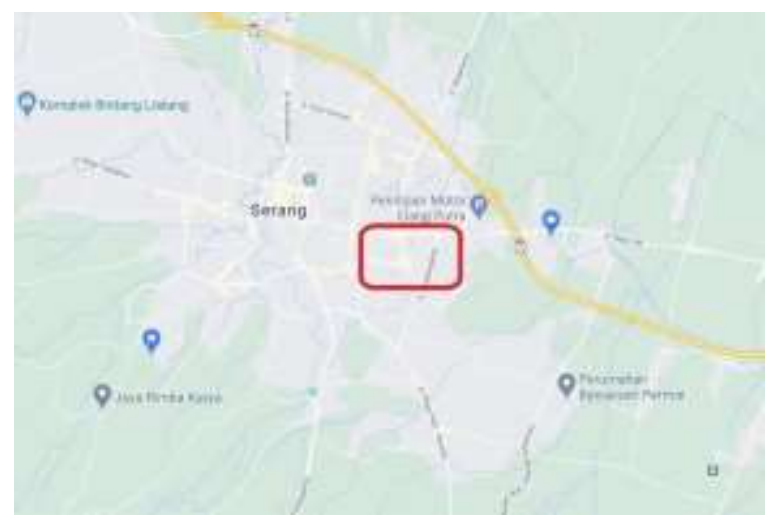

Gambar 6. Lokasi PPM Pencak Silat

\section{Media Sosial Wisata pencak silat}

Media sosial merupakan program usulan dari Tim PPM yang sudah terselenggarakan dengan menggunakan dua media sosial yang mayoritas masyarakat memiliki media sosial tersebut yaitu Facebook dan Instagram untuk mempromosikan dan menginformasikan edukasi tentang kesenian pencak silat. 
ISSN : :2686-6447

Jurnal ABDIKARYA

E-ISSN : 2715-6605

Volume 3, No. 2, Oktober 2021

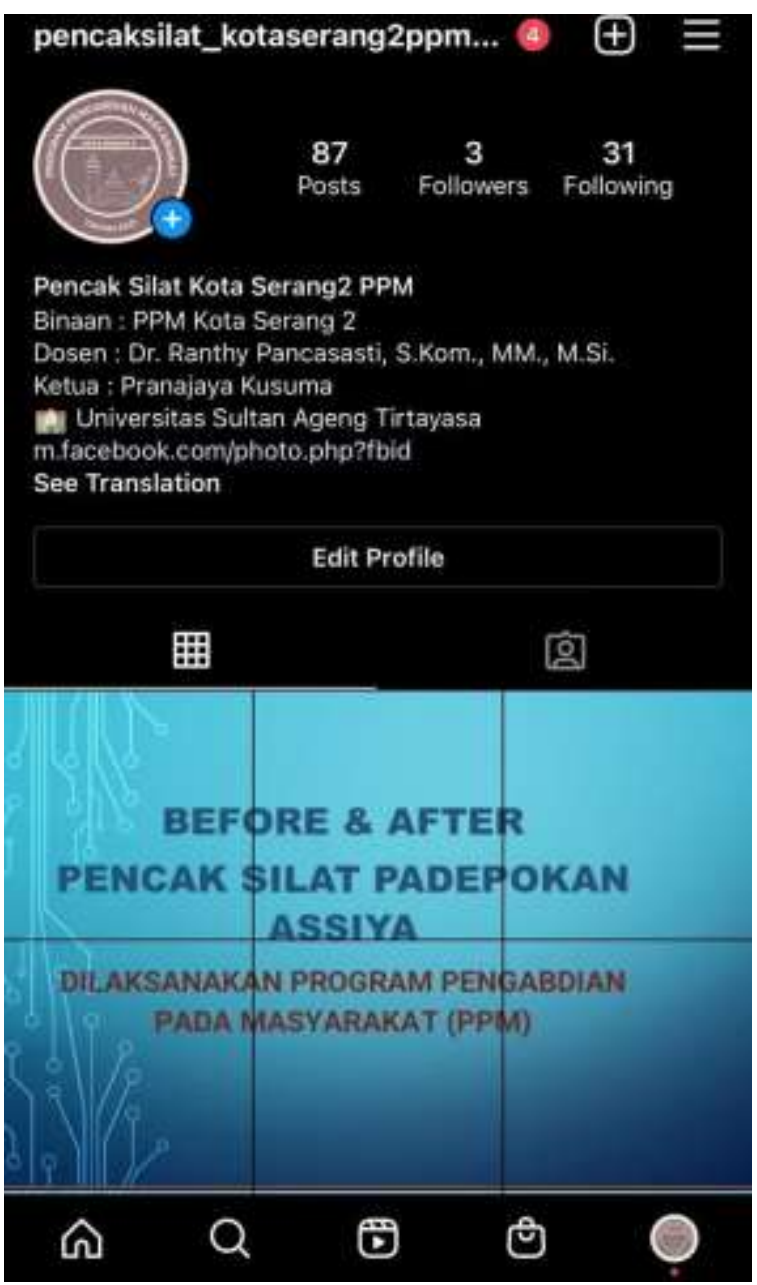

Gambar 7. Akun Instagram Pecak Silat
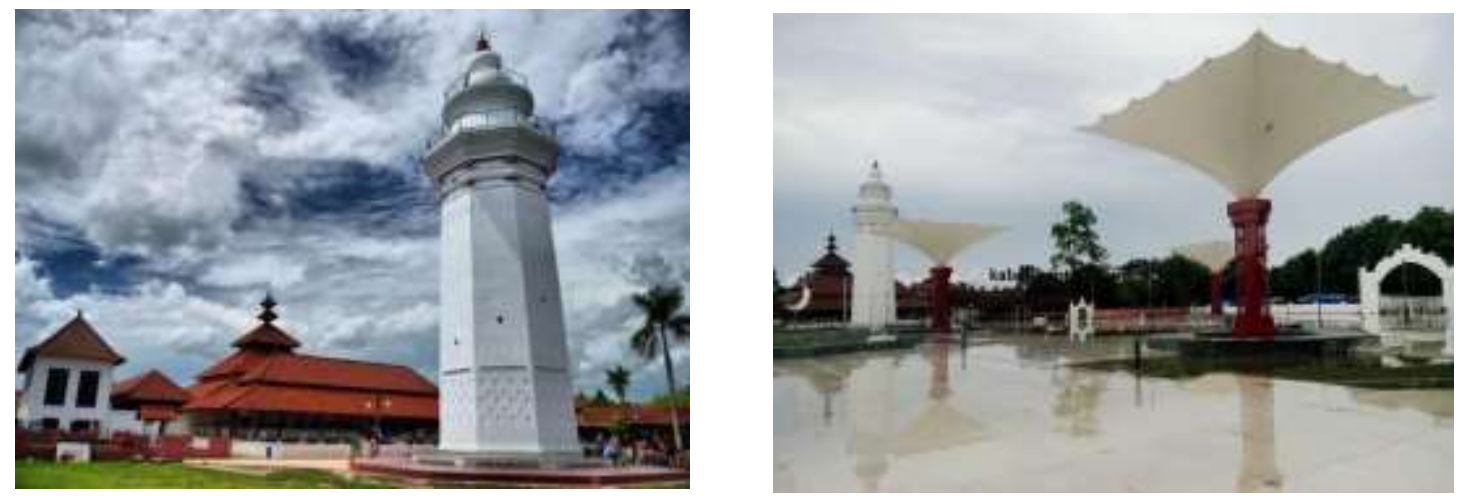

Gambar 8. Sebelum dan Sesudah Dilaksanakannya Program PPM 
Pada gambar di atas, menunjukkan wisata Banten Lama sebelum dilaksanakannya program PPM, Banten lama adalah tempat wisata yang sangat tradisional dan perlu adanya upaya pelestarian.
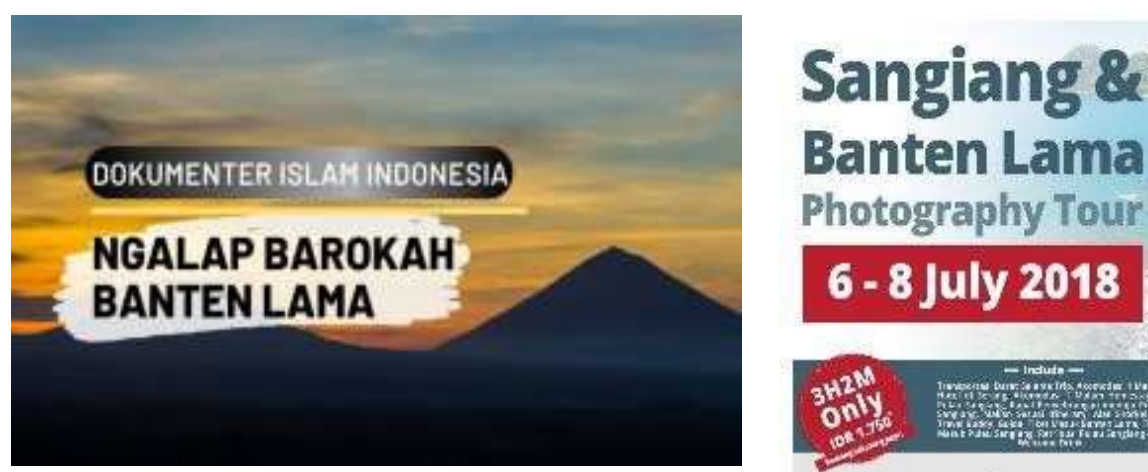
Banten Lama Photography Tour
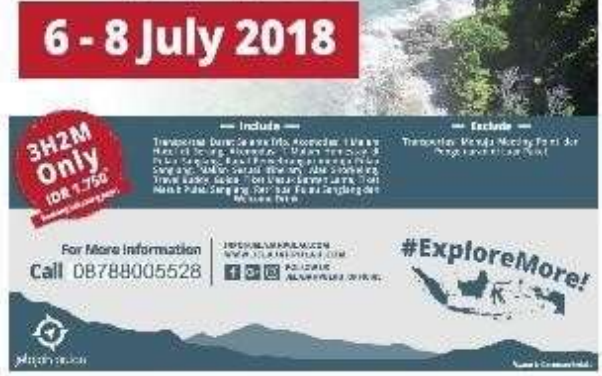

\section{Gambar 9. Wisata Banten Lama}

Pada gambar di atas, menunjukkan wisata Banten Lama sesudah dilaksanakannya program PPM, wisata Banten Lama meningkatkan wisatawan dan upaya pelestarian dilakukan dengan membuat video dokumenter serta paket wisata ke Banten Lama dengan ini dapat membuat wisata Banten Lama dikenal masyarakat Daerah maupun Luar Daerah.

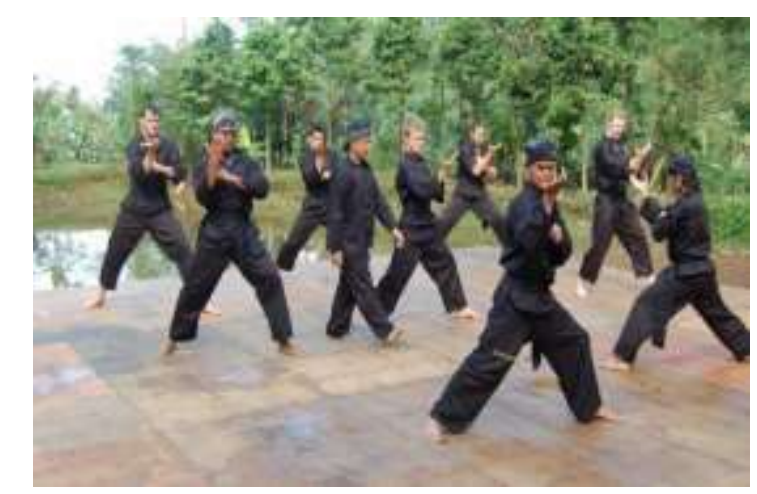

Gambar 10. Pencak Silat Sebelum Program PPM

Pada gambar di atas, menunjukkan Budaya Pencak Silat sebelum dilaksanakannya program PPM. Budaya Seni Pencak Silat dilihat dari pandangan masyarakat hanya sekedar sebuah ilmu bela diri saja. Pelestarian pada warisan Budaya Pencak Silat ini pada awalnya dinilai masih sangat rendah. 


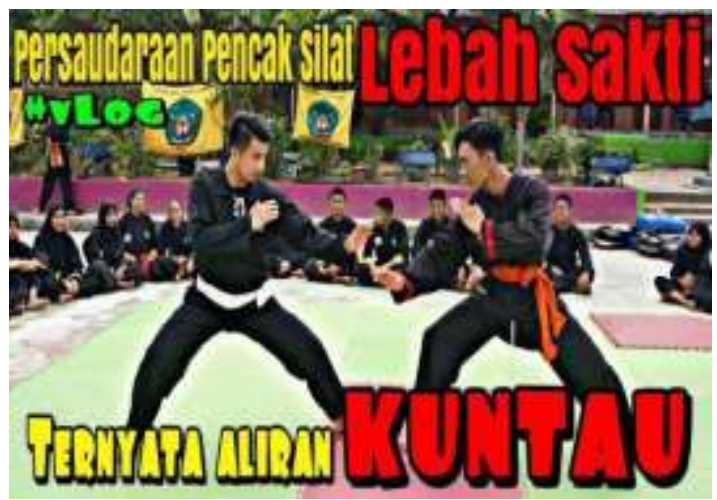

\section{Gambar 11. Pencak Silat Setelah Program PPM}

Pada gambar di atas, menunjukkan Budaya Pencak Silat setelah dilaksanakannya program PPM. Setelah dilaksanakan program PPM membuat masyarakat tidak hanya berpikir bahwa Pencak Silat bukan hanya sekedar ilmu bela diri saja tapi merupakan sebuah kesenian yang tetap harus dilestarikan untuk menjadi sebuah indentitas, dengan diadakannya Festival Pencak silat dan ada nya Vlog atau video yang akan diupload di media sosial ini dapat membuat masyarakat tertarik dan mengetahui serta menjadikannya tetap eksis dikalangan masyarakat.

\section{Proses Pembuatan Media Sosial}

Pembuatan akun media sosial guna mempromosikan Pencak Silat dan Wisata Banten Lama yaitu melalui media sosial Facebook dan Instagram. Masing-masing PPM Pencak Silat dan Wisata Banten Lama memiliki akun yang berbeda. Hal tersebut ditujukan agar kegiatan promosi dapat lebih efektif dan efisien.

\section{a. Pembuatan Akun Instagram Wisata Banten Lama}

Pembuatan Akun instagram Wisata Banten Lama melalui beberapa langkah sebagai berikut:

1. Membuat akun email untuk mendaftar

2. Membuat akun instagram dengan email yang sudah dibuat sebelumnya

3. Menentukan username yaitu bantenlama_kotaserang2_pp m2021

4. Mengisi biodata yang terdapat pada instagram yang berisi Dosen Pembimbing yaitu Dr. Ranthy Pancasasti, S.Kom., M.M., M.Si. dan ketua kelompok yaitu Pranajaya Kusuma

5. Mengupload konten yang berisi Lokasi, Peta, Harga Tiket Masuk, Keunggulan Wisata Banten Lama, serta Keadaan Sebelum dan Sesudah dilaksanakannya program. 

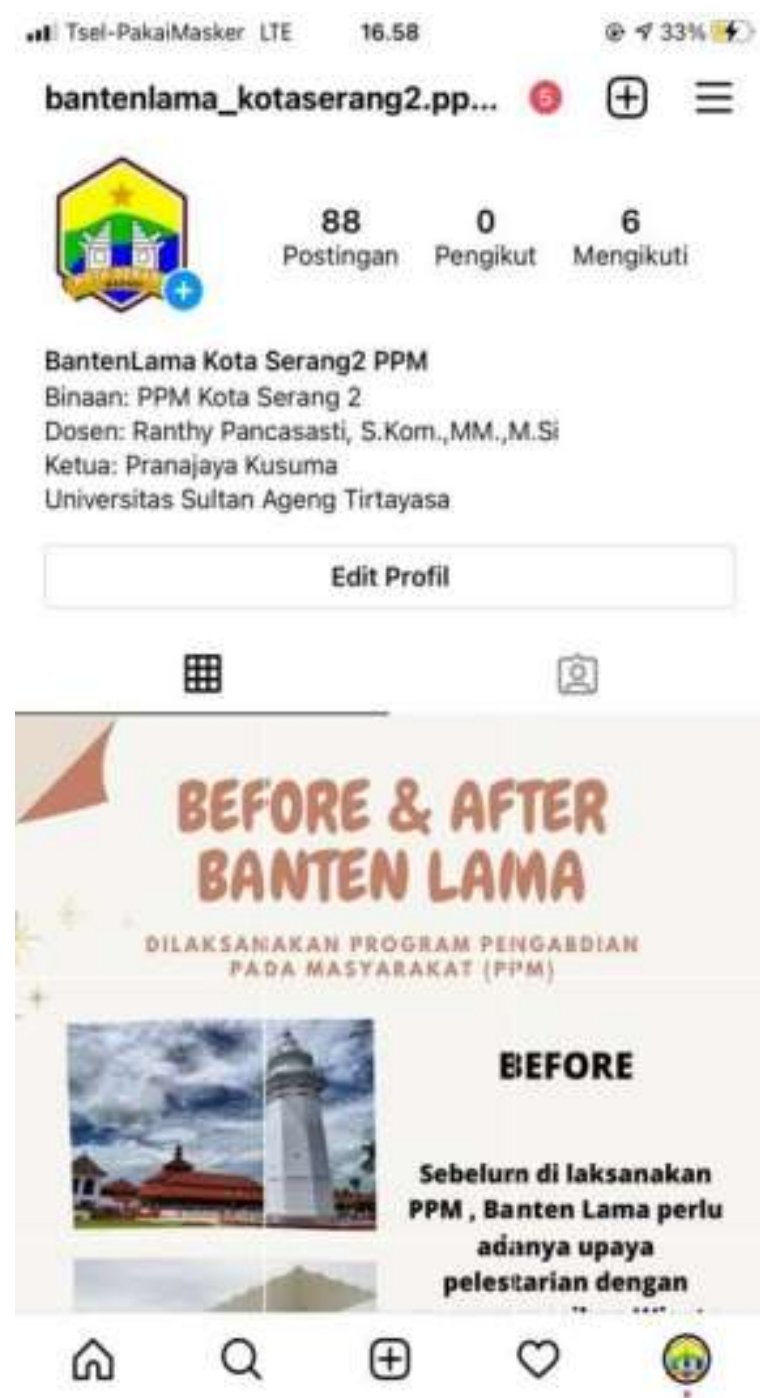

Gambar 12. Akun Instragram Wisata Banten Lama

\section{b. Alur Pembuatan Instagram Pencak Silat}

Pembuatan Akun instagram Pencak Silat melalui beberapa langkah sebagai berikut:
a. Membuat akun email untuk mendaftar
b. Membuat akun instagram dengan email yang sudah dibuat sebelumnya
c. Menentukan username yaitu pencak_silat_kotser2ppm2021
d. Mengisi biodata yang terdapat pada instagram yang berisi Dosen pembimbing yaitu Dr. Ranthy Pancasasti, S.Kom., M.M., M.Si. dan ketua kelompok yaitu Pranajaya Kusuma
e. Mengupload konten yang berisi Lokasi, Peta, Harga Tiket Masuk, Keunggulan Pencak Silat, serta Keadaan Sebelum dan Sesudah dilaksanakannya program. 


\section{c. Alur Pembuatan Facebook Banten Lama}

Pembuatan Akun facebook Banten Lama melalui beberapa langkah sebagai berikut:

1. Membuat akun email untuk mendaftar

2. Membuat akun Facebook dengan email yang sudah dibuat sebelumnya

3. Membuat halaman untuk selanjutnya digunakan sebagai mempromosikan Banten Lama dengan nama PPM Kota Serang Banten Lama.

4. Mengisi biodata yang terdapat pada Halaman Facebook yang berisi Dosen pembimbing yaitu Dr. Ranthy Pancasasti, S.Kom., M.M., M.Si. dan ketua kelompok yaitu Pranajaya Kusuma.

5. Mengupload konten yang berisi Lokasi, Peta, Harga Tiket Masuk, Keunggulan Banten Lama, Keadaan Sebelum dan Sesudah dilaksanakannya program.

\section{d. Pembuatan Akun Facebook Pencak Silat}

Pembuatan Akun Facebook pencak silat melalui beberapa langkah sebagai berikut:

1. Membuat akun email untuk mendaftar

2. Membuat akun Facebook dengan email yang sudah dibuat sebelumnya

3. Membuat halaman untuk selanjutnya digunakan sebagai mempromosikan Pencak Silat dengan nama PPM Kota Serang Pencak Silat

4. Mengisi bio yang terdapat pada Halaman Facebook yang berisi Dosen pembimbing, yaitu Dr. Ranthy Pancasasti, S.Kom., M.M., M.Si. dan ketua kelompok yaitu Pranajaya Kusuma

5. Mengupload konten yang berisi Lokasi, Peta, Harga Tiket Masuk, Keunggulan Pencak Silat, Keadaan Sebelum dan Sesudah dilaksanakannya program.

\section{e. Sosialisasi Program PPM}

Dikarenakan kondisi yang tidak memungkinkan untuk mengadakan sosialisasi atau berkumpul secara langsung, maka Tim PPM melaksanakan sosialisasi melalui Zoom Meeting. Sosialisasi secara daring ini juga menghadirkan Dosen Pembimbing dan Narasumber.

\section{KESIMPULAN}

Pengabdian Pada Masyarakat (PPM) adalah suatu kegiatan yang melibatkan mahasiswa untuk turun dan mengabdi kepada masyarakat sebagai wahana penyempurnaan proses belajar mahasiswa. PPM sebagai bentuk dari perwujudan rasa tanggung jawab mahasiswa untuk 
melaksanakan salah satu Tri Dharma perguruan tinggi yaitu pengabdian kepada masyarakat. Kegiatan PPM menjadikan mahasiswa lebih tanggap dan peka terhadap permasalahan yang ada dalam kehidupan masyarakat. Dengan adanya PPM mahasiswa diharapkan dapat menyelesaikan segala permasalahan yang ada dan mampu untuk menerapkan ilmu-ilmu yang telah diperolehnya dibangku kuliah, dan dipusatkan pada kehidupan masyarakat agar dapat lebih mensejahterakan masyarakat. Kehadiran mahasiswa di tengah-tengah masyarakat secara langsung belum dapat merubah kehidupan masyarakat ke arah yang lebih maju dalam sekejap, tetapi dengan kehadiran mahasiswa peserta PPM ternyata dapat merubah pola pikir masyarakat menuju ke arah yang lebih baik. Mahasiswa harus mampu menjadi penggerak pembangunan yang mampu membawa perubahan dan kemajuan di segala aspek kehidupan.

\section{TANDA TERIMAKASIH}

Tanda terimakasih atas terselenggaranya PPM ini dberikan kepada:

1. Rektor Untirta, Prof. Dr. Fatah Sulaiman, ST., MT

2. Ketua LPPM Untirta, Dr. Ir. Rusmana, M.Si

3. Dekan FEB Untirta, Dr. Akhmadi, SE., MM

4. Wakil Dekan Bidang Akademik FEB Untirta, Dr. Indra Suhendar, SE., M.Si

5. Ketua Jurusan Manajemen, Dr. Lufti, SE., MM

6. Pengurus Padepokan Assyfa Kota Serang

7. Pengurus Wisata Banten Lama

8. Pemimpin Banten Tour and Travel

9. Mahasiswa Jurusan Manajemen FEB Untirta, khususnya semester 6.

\section{REFERENCES}

Astiti, N. K. A. (2014). Pengelolaan Kawasan Situs Kota Kuno Banten sebagai Destinasi Wisata Budaya untuk Meningkatkan Pergerakan Wisatawan Nusantara. BPS Kota Serang 2015 2019.

Ghufron. (2012). Sejarah dan Kebudayaan Provinsi Banten. Website http://budayabanten.blogspot.com/ Diakses pada Tanggal 3 April 2021.

Havidani, A., Srimulyawati, L., Arif, I. (2018). Arahan Pengembangan Wisata Sosial-Budaya Di Kawasan Strategis Banten Lama Kota Serang. Jurnal Online Mahasiswa (JOM) Bidang Perencanaan Wilayah \& Kota. Volume 1(1) Nomor 1.

Irhandayaningsih, A. (2018). Pelestarian Kesenian Tradisional sebagai Upaya dalam Menumbuhkan Kecintaan Budaya Lokal di Masyarakat Jurang Blimbing Tembalang. Anuva, 2(1), 19. 
Medtry, M., Madjid, K., dan Wibowo, J. A. (2019, October). Strategi Pengembangan Pariwisata Terpadu Studi Kasus: Kawasan Banten Lama Kecamatan Kasemen Kota Serang. In TECHNOPEX 2019.

Pradani, R. A., Herlambang, S., dan Santoso, S. (2020). Studi Integrasi Wisata Religius Dan Wisata Bahari (Objek Studi: Kawasan Banten Lama Dan Pelabuhan Karangantu). Jurnal Sains, Teknologi, Urban, Perancangan, Arsitektur (Stupa), 2(2), 2743-2758.

Wahdatunnisa, A. (2017). Peranan H. Muhammad Senin Dalam Mengembangkan Pencak Silat Di Padepokan Pusaka Saputra Paku Banten Gunung Kaler Kresek Tahun 1992-2007. Skripsi. Fakultas Ushuludin dan Adab, Banten. 